\title{
The tsunami source area of the 2003 Tokachi-oki earthquake estimated from tsunami travel times and its relationship to the 1952 Tokachi-oki earthquake
}

\author{
Kenji Hirata $^{1}$, Yuichiro Tanioka ${ }^{2}$, Kenji Satake $^{3}$, Shigeru Yamaki ${ }^{4}$, and Eric. L. Geist ${ }^{5}$ \\ ${ }^{1}$ Deep Sea Research Department, Japan Marine Science and Technology Center, 2-15 Natsuhima-cho, Yokosuka 237-0061, Japan \\ ${ }^{2}$ Institute of Seismology and Volcanology, Hokkaido University, N10W8 Kita-ku, Sapporo 060-0810, Japan \\ ${ }^{3}$ Active Fault Research Center, National Institute of Advanced Industrial Science and Technology, Site C7 1-1-1 Higashi, Tsukuba 305-8567, Japan \\ ${ }^{4}$ Seamus Ltd., 2235 Kizaki, Toyosaka 950-3304, Japan \\ ${ }^{5}$ U.S. Geological Survey, 345 Middlefield Road, Menlo Park, 94025, CA, USA
}

(Received November 16, 2003; Revised February 26, 2004; Accepted Feburary 26, 2004)

\begin{abstract}
We estimate the tsunami source area of the 2003 Tokachi-oki earthquake (Mw 8.0) from observed tsunami travel times at 17 Japanese tide gauge stations. The estimated tsunami source area $\left(\sim 1.4 \times 10^{4} \mathrm{~km}^{2}\right)$ coincides with the western-half of the ocean-bottom deformation area $\left(\sim 2.52 \times 10^{4} \mathrm{~km}^{2}\right)$ of the 1952 Tokachi-oki earthquake (Mw 8.1 ), previously inferred from tsunami waveform inversion. This suggests that the 2003 event ruptured only the western-half of the 1952 rupture extent. Geographical distribution of the maximum tsunami heights in 2003 differs significantly from that of the 1952 tsunami, supporting this hypothesis. Analysis of first-peak tsunami travel times indicates that a major uplift of the ocean-bottom occurred approximately $30 \mathrm{~km}$ to the NNW of the mainshock epicenter, just above a major asperity inferred from seismic waveform inversion.
\end{abstract}

Key words: The 2003 Tokachi-oki earthquake, tsunami, tide gauge records, the 1952 Tokachi-oki earthquake.

\section{Introduction}

A large inter-plate earthquake occurred on September 26, 2003 (Japanese Standard Time; JST) at the southwestern end of the Kuril Trench offshore Hokkaido, Japan. The Japan Meteorological Agency (JMA) named this earthquake "the 2003 Tokachi-oki earthquake". This earthquake occurred in the same region as the 1952 Tokachi-oki earthquake (Mw 8.1). Hypocentral parameters of the 2003 Tokachi-oki earthquake determined by JMA are as follows: origin time = 4:50:07.5 sec (JST); lat. $=41^{\circ} 46.7^{\prime} \mathrm{N}$; long. $=144^{\circ} 04.7^{\prime} \mathrm{E}$ depth $=42 \mathrm{~km} ; \mathrm{M}_{J} 8.0$, where $\mathrm{M}_{J}$ is the JMA magnitude scale. Maximum seismic intensity of " 6 minus" on the new JMA scale (corresponding to IX on the modified Mercalli scale) was observed in the Tokachi Plain, Hokkaido. The earthquake generated a tsunami that caused damage along the Hokkaido coast. JMA issued the first tsunami warning for the Pacific coast of the Hokkaido and northern Honshu 6 minutes after the mainshock.

Yamanaka and Kikuchi (2003), using the well-established body-wave inversion (Kikuchi and Kanamori, 2003), have estimated the slip distribution of the 2003 Tokachi-oki earthquake from teleseismic records and of the 1952 event from nearby strong-ground motion records. They have suggested that the 2003 event has only one major asperity and that it coincides with at least one of the 1952 asperities. As they note, their results for the 1952 event represent only the initial rupture stage, rather than the total source process, because the 1952 strong-motion records went off-scale soon

Copy right(c) The Society of Geomagnetism and Earth, Planetary and Space Science (SGEPSS); The Seismological Society of Japan; The Volcanological Society of Japan; The Geodetic Society of Japan; The Japanese Society for Planetary Sciences; TERRAPUB after the $S$-wave arrivals. On the other hand, tsunami waveform inversion by Hirata et al. (2003) have indicated that the 1952 event had two large slip regions. One of them seems to be located in the same region as the 2003 asperity estimated by Yamanaka and Kikuchi (2003), and the other is located further east, offshore Kushiro.

To evaluate relationship between the 1952 and 2003 earthquakes from the viewpoint of tsunamis, we collected tide gauge records on the coasts of the northern Japan and estimate the 2003 tsunami source area from the observed tsunami travel times. Then, we compare the 2003 and 1952 tsunami source areas. Such a comparison is one of keys to determine whether the 2003 earthquake was a repeat of the 1952 earthquake.

\section{Tide Gauge Records and Tsunami Travel Times}

We collected tide gauge records from stations located on the Pacific coasts in Hokkaido and northern Honshu, Japan, as shown in Fig. 1. These records are provided by JMA, the Hokkaido Regional Development Bureau (HRDB) of the Ministry of Land, Infrastructure and Transport, and the Hydrographic and Oceanographic Department (HOD) of the Japan Coast Guard. JMA, HRDB, and HOD tide gauge records are recorded digitally and are sampled at 1-minute (JMA and HRDB) and at 30-seconds (HOD). Most of the these tide gauge records show that the tsunami first motion was upward, suggesting uplift of the seafloor in the 2003 tsunami source area (Fig. 1).

We pick onset times (red triangles in Fig. 1) of first tsunami waves and times when the tsunami reaches the first peak (green triangles), and list them in Table 1. We call the latter the first-peak time. Errors in picking these tsunami ar- 


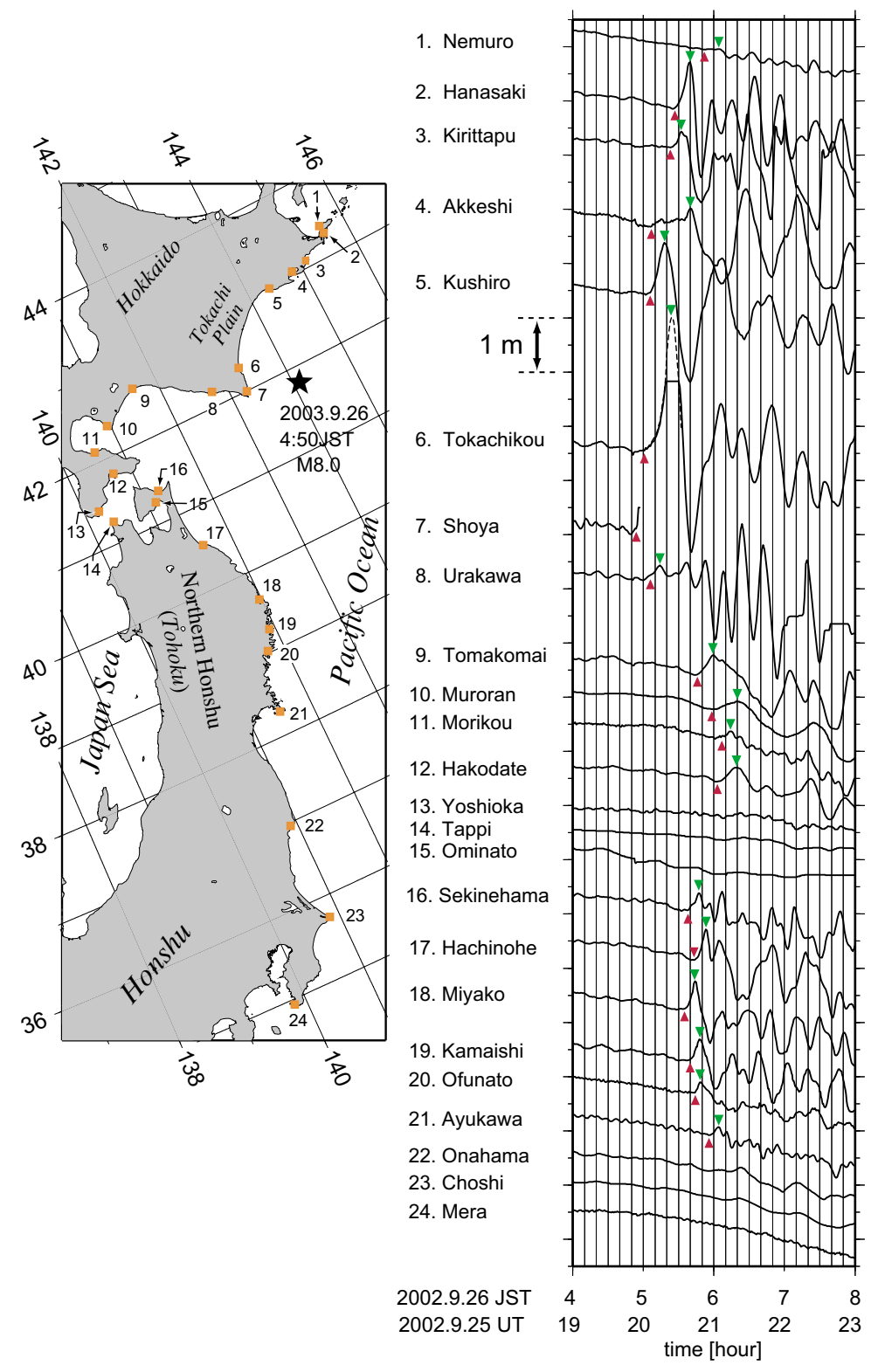

Fig. 1. Tide gauge stations (orange squares in left panel) and observed tide gauge records (right panel) collected for the 2003 Tokachi-oki earthquake. Solid star in left panel represents the epicenter of the mainshock. Arrival (onset) times of first tsunami waves and the first-peak times are depicted by red and green triangles, respectively. All tide gauge records are plotted on the same scale. The record at Shoya (\#7 in the left panel) went off-scale soon after tsunami onset. The record at Tokachikou (\#6) appears to scale-out around the first peak but this can be reconstructed. (See text.)

rivals seem to be within a few minutes on average.

Tide gauge records from Yoshioka (\#13), Tappi (\#14), Ominato (\#15), Onahama (\#22), Choshi (\#23), and Mera (\#24) show small tsunami amplitudes less than $0.2 \mathrm{~m}$ (very low $\mathrm{S} / \mathrm{N}$ ratios) in their first cycles (Fig. 1), making first arrival picks difficult. We decide not to use these six records. The amplitude of the first tsunami arrival at Nemuro (\#1) is small but easily visible because the background level before the first arrival is also relatively small. The initial 30-minutes signal of the tide gauge record at Akkeshi (\#4) is complicated; possible strong ground shaking due to the earthquake may have produced a secondary water disturbance within the Akkeshi Bay, which makes picking of the onset somewhat inaccurate. The earliest tsunami arrival (4 minutes) was observed at Shoya (\#7). The tsunami rose quickly there and the tide gauge record went off scale soon. The first-peak time at Shoya, therefore, is unknown. The tide gauge record at Tokachikou (\#6) shows that the amplitude of the first tsunami peak increased past the limits of the data-transmission system from twenty to thirty minutes after the tsunami onset. Fortunately, staff at the HRDB branch who were wakened by the earthquake came to their office very early in the morning and hand wrote tsunami heights at one minute intervals by watching a real-time tsunami height indicator which has an independent data-transmission system (broken line in Fig. 1). Therefore, we can reconstruct the complete tsunami waveform at Tokachikou. Tide gauge records at Muroran (\#10) and Hakodate (\#12) show apparent long-period component that is probably caused by eigen-oscillations of seawater, such as a seiche, within the port or bay. Tsunami arrival times picked at the two stations may be less accurate. 


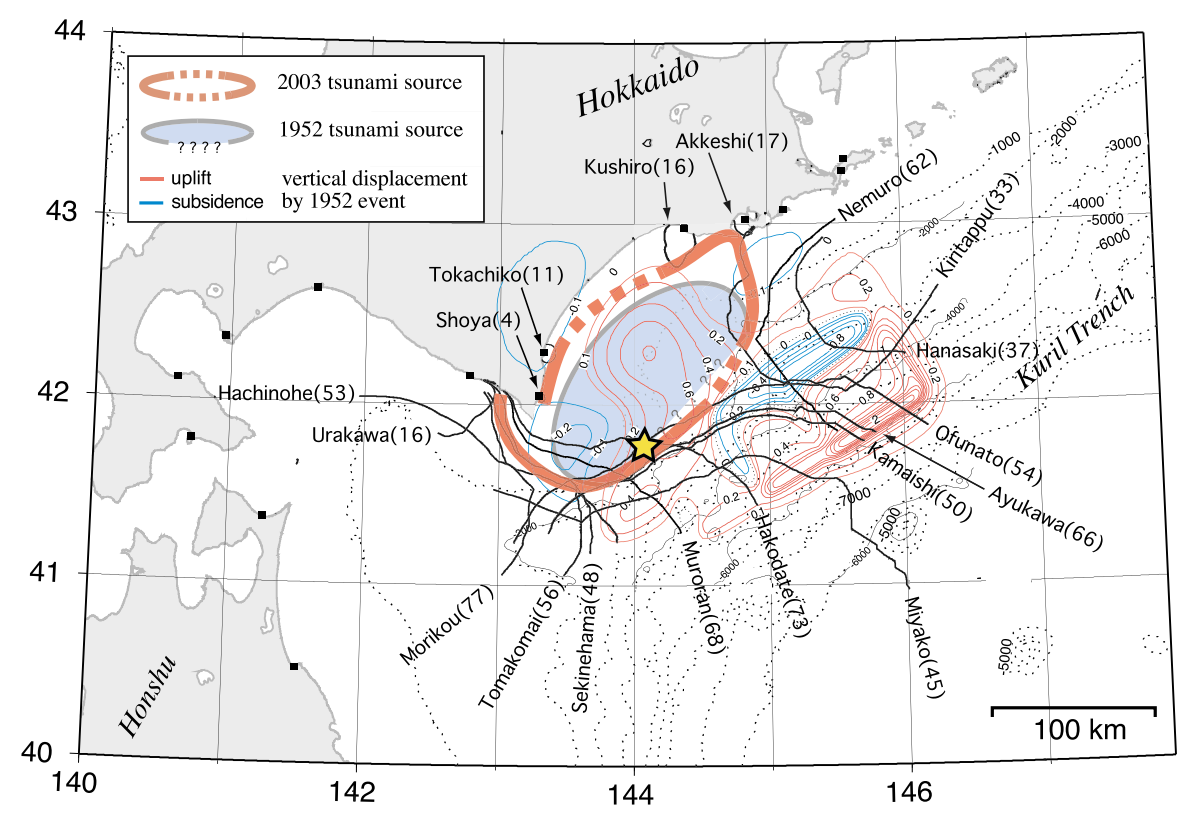

Fig. 2. The 2003 tsunami source area (thick red line) estimated from tsunami travel times in comparison to the 1952 tsunami source area (shaded blue ellipse) by Hatori (1973). Black lines represent the imaginary back-going wave fronts with the observed onset times from tide gauge stations listed in Table 1. Numerals within parentheses beside station names indicate the observed onset times in minutes. The deformation pattern of the ocean-bottom calculated from slip distribution of the 1952 event (Hirata et al., 2003) is shown by red (uplift) and blue (subsidence) counters. A yellow star represents the epicenter of the 2003 event.

Table 1. The tsunami arrivals from the 2003 Tokachi-oki Earthquake*1.

\begin{tabular}{|c|c|c|c|c|c|c|c|}
\hline \multirow[b]{2}{*}{$\#$} & \multirow[b]{2}{*}{ tide gauges } & \multicolumn{3}{|c|}{ initial waves (onset) } & \multicolumn{2}{|c|}{ initial waves (1-st peak) } & \multirow[b]{2}{*}{ remarks } \\
\hline & & $\begin{array}{l}\text { arrival times }{ }^{* 2} \\
\text { (h:min) }\end{array}$ & $\begin{array}{l}\text { travel times } \\
\text { (minutes) }\end{array}$ & polarity & 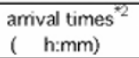 & $\begin{array}{r}\text { travel times } \\
\text { (minutes) }\end{array}$ & \\
\hline & Hokkaido & & & & & & \\
\hline 1 & Nemuro & $5: 52$ & 62 & up & $6: 04$ & 74 & \\
\hline 2 & Hanasaki & $5: 27$ & 37 & up & $5: 40$ & 50 & \\
\hline 3 & Kiritappu & $5: 23$ & 33 & up & $5: 32$ & 42 & \\
\hline 4 & Akkeshi & $5: 07$ & 17 & up & $5: 40$ & 50 & \\
\hline 5 & Kushiro & $5: 06$ & 16 & up & $5: 18$ & 28 & \\
\hline 6 & Tokachiko & 5.01 & 11 & up & $5: 23$ & 33 & \\
\hline 7 & Shoya & $4: 54$ & 4 & up & - & - & \\
\hline 8 & Urakawa & $5: 06$ & 16 & up & $5: 14$ & 24 & low $\mathrm{S} / \mathrm{N}$ \\
\hline 9 & Tomakomai & $5: 46$ & 56 & up & $5: 59$ & 69 & \\
\hline 10 & Muroran & $5: 58$ & 68 & up & $6: 20$ & 90 & low $\mathrm{S} / \mathrm{N}$, long-period \\
\hline 11 & Morikou & $6: 07$ & 77 & up & $6: 14$ & 84 & \\
\hline 12 & Hakodate & $6: 03$ & 73 & up & $6: 19$ & 89 & low $\mathrm{S} / \mathrm{N}$, long-period \\
\hline 13 & Yoshioka & - & - & up? & - & - & low $\mathrm{S} / \mathrm{N}$ \\
\hline & Tohoku & & & & & & \\
\hline 14 & Tappi & - & . & up? & . & . & low $S / N$ \\
\hline 15 & Ominato & - & - & : & - & - & low $S / N$ \\
\hline 16 & Sekinehama & $5: 38$ & 48 & up & $5: 47$ & 57 & \\
\hline 17 & Hachinohe & $5: 43$ & 53 & up & $5: 53$ & 63 & \\
\hline 18 & Miyako & $5: 35$ & 45 & up & $5: 43$ & 53 & \\
\hline 19 & Kamaishi & $5: 40$ & 50 & up & $5: 48$ & 58 & \\
\hline 20 & Ofunato & $5: 44$ & 54 & up & $5: 48$ & 58 & \\
\hline 21 & Ayukawa & $5: 56$ & 66 & up & $6: 04$ & 74 & \\
\hline 22 & Onahama & - & - & up? & - & - & low $S / N$ \\
\hline 23 & Choshi & - & - & up? & - & - & low $\mathrm{S} / \mathrm{N}$ \\
\hline 24 & Mera & - & - & - & - & - & low $\mathrm{S} / \mathrm{N}$ \\
\hline
\end{tabular}

\section{The 2003 Tsunami Source Area}

We estimate the tsunami source area of the 2003 Tokachioki earthquake from the tsunami arrival (onset) times at 12 tide gauge stations (\#1 to \#12) in Hokkaido and 5 (\#16 to \#21) in northern Honshu. An imaginary wave front to a given tide gauge station can be traced backwards from the station to a possible tsunami source area with the observed travel time over a distance equal to $c t$ where $c$ is a long-wave velocity $(g h)^{1 / 2}$ ( $g=$ gravitational acceleration, $h=$ water depth), and $t$ is the travel time of tsunami. We calculate the imaginary back-going wave front from a given tide gauge station using bathymetry provided by HOD. The grid size of the bathymetric database is 10 arc-seconds.

Figure 2 shows the tsunami source area of the 2003 Tokachi-oki earthquake estimated by using this technique (thick red line). The area size is estimated to be approximately $1.4 \times 10^{4} \mathrm{~km}^{2}$. The 2003 tsunami source area is well defined from the onset times of almost all the tide gauge stations except for a few stations. The estimated tsunami source area is not well constrained on its northwestern side (about 80-km-long) because no tide gauge station is located between Kushiro (\#5) and Tokachikou (\#6). Also, a small 


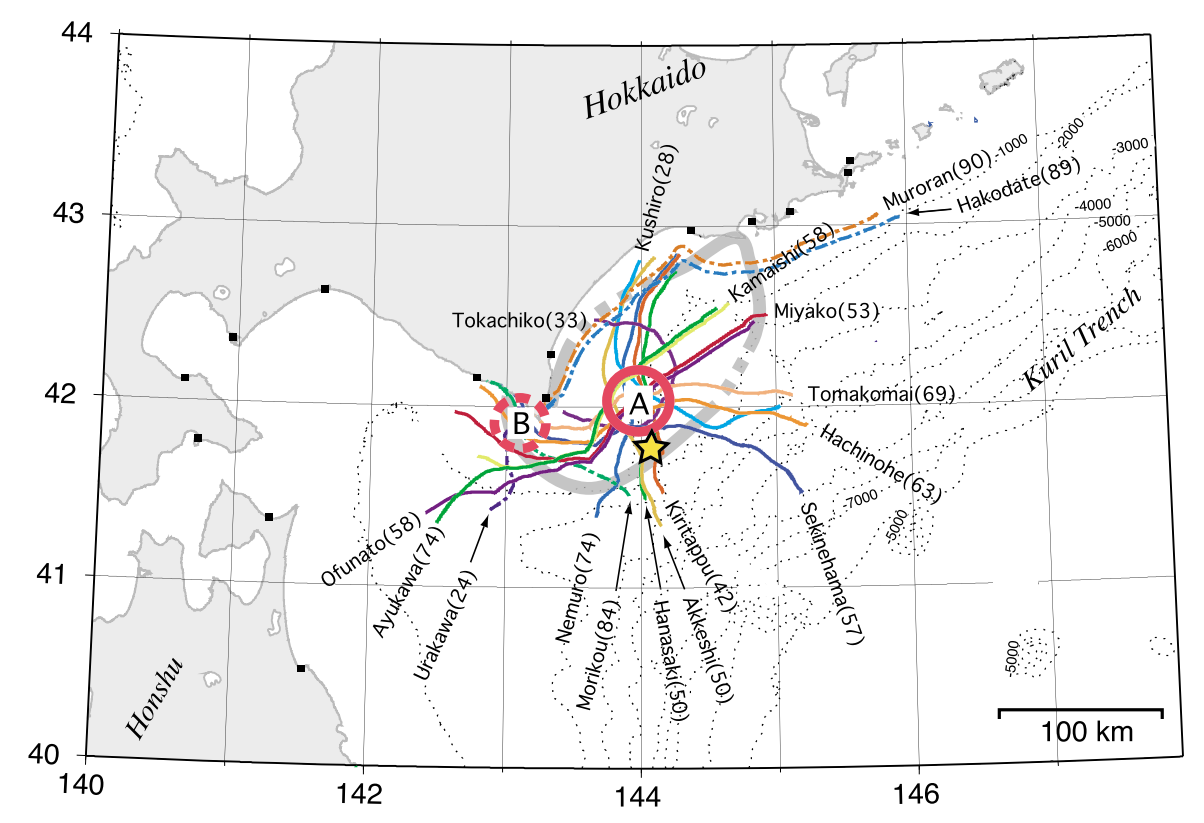

Fig. 3. First-peak travel times showing uplift regions within the 2003 tsunami source area. Twelve out of 16 imaginary back-going wave fronts with observed first-peak times converge into a circular region A (red solid circle). This represents a region of major uplift. Region B (red broken circle) appears to indicate a minor uplift of the seafloor or diffraction ("Huygens") source at Cape Erimo.

segment (about 30-km-long) of its southeastern side is not well constrained. To constrain the southeastern side, Russian tide gauge records in the Kuril Islands would be useful, yet we do not have those. As we mentioned in the previous section, estimation of the observed onset time (first arrival time) for Akkeshi (\#4) is somewhat inaccurate. However, the location of the imaginary back-going wave front from Akkeshi is probably not greatly affected by the inaccuracy. Bathymetry in the Akkeshi Bay (mostly $<20 \mathrm{~m}$ depth) and within approximately $10 \mathrm{~km}$ offshore of the bay $(<100 \mathrm{~m}$ depth) is shallow enough to restrict the tsunami wave front near the coast (see Fig. 2). Even if we misread the observed travel time for Akkeshi 10 minutes earlier, the location of the imaginary wave front only moves approximately $13 \mathrm{~km}$ trenchward. The onset signal at Nemuro (\#1) is small but visible enough to well define the eastern boundary of the estimated tsunami source, in addition to the arrival at Kiritappu (\#3). The imaginary back-going wave fronts from Hanasaki (\#2) and Miyako (\#18) do not reach any edge of the estimated tsunami source. In other words, the observed travel times from these two stations are early by a few minutes. Shallow bathymetry around these tide gauge stations might include a systematic error in water depth. In contrast, the observed travel times from Muroran (\#10) and Hakodate (\#12) are somewhat late. We discuss the observed travel times from Muroran and Hakodate below.

The 2003 tsunami source area estimated in this paper nearly coincides with the 1952 tsunami source area estimated by Hatori (1973), although it should be noted that, as Hatori (1973) mentioned in his article, his tsunami source area is not constrained on a vast segment (about 100-km-long) of its southeastern-side (trenchward) boundary from any of the available tide gauge records. Hirata et al. (2003) indicated from tsunami waveform inversion of the 1952 Tokachi-oki earthquake that the deformation area $\left(\sim 2.52 \times 10^{4} \mathrm{~km}^{2}\right)$ also extended to the east (trenchward) in the deep seafloor of Hatori's (1973) tsunami source area $\left(\sim 8.8 \times 10^{3} \mathrm{~km}^{2}\right)$. From the present analysis, the 2003 tsunami source area only covers the western half of the 1952 tsunami source area. This means that the eastern half of the region ruptured by the 1952 Tokachi-oki earthquake may remain unbroken. Tanioka et al. (2004a), who inverted the observed tide gauge records to estimate the slip distribution of the 2003 event, also support this hypothesis.

Next we calculate the imaginary back-going wave fronts from the observed first-peak times listed in Table 1. Figure 3 shows the results. Excluding Shoya (\#4) where the first tsunami scaled out soon after the onset, the imaginary backgoing wave fronts from 12 tide gauge stations converge into a circular region, A, with a diameter of about $40 \mathrm{~km}$ (thick red circle). Region A is located approximately $30 \mathrm{~km}$ to the NNW of the mainshock epicenter (Fig. 3) and just above the main asperity of the 2003 earthquake estimated by Yamanaka and Kikuchi (2003). We attribute region A as the major uplift center of the seafloor due to the 2003 event.

On the other hand, the imaginary back-going wave fronts with the observed first-peak times from Urakawa (\#8) and Morikou (\#11) do not reach region A, but both intersect at a region, named B (broken, red circle in Fig. 3). A minor uplift of the seafloor possibly occurred at region B during the 2003 event. If this is the case, the imaginary back-going fronts with the observed first-peak times from Muroran (\#10) and Hakodate (\#12) may also reach region $\mathrm{B}$, because the two tide gauge stations are located to the west of the 2003 tsunami source area, as are Urakawa (\#8) and Morikou (\#11). The imaginary back-going wave fronts from Muroran (\#10) and Hakodate (\#12), however, pass by region B, even by region $\mathrm{A}$, and reach near the Tokachi coast (Fig. 3). This is very enigmatic. We suspect that we could not correctly read the first-peak times for Muroran (\#10) and Hakodate 


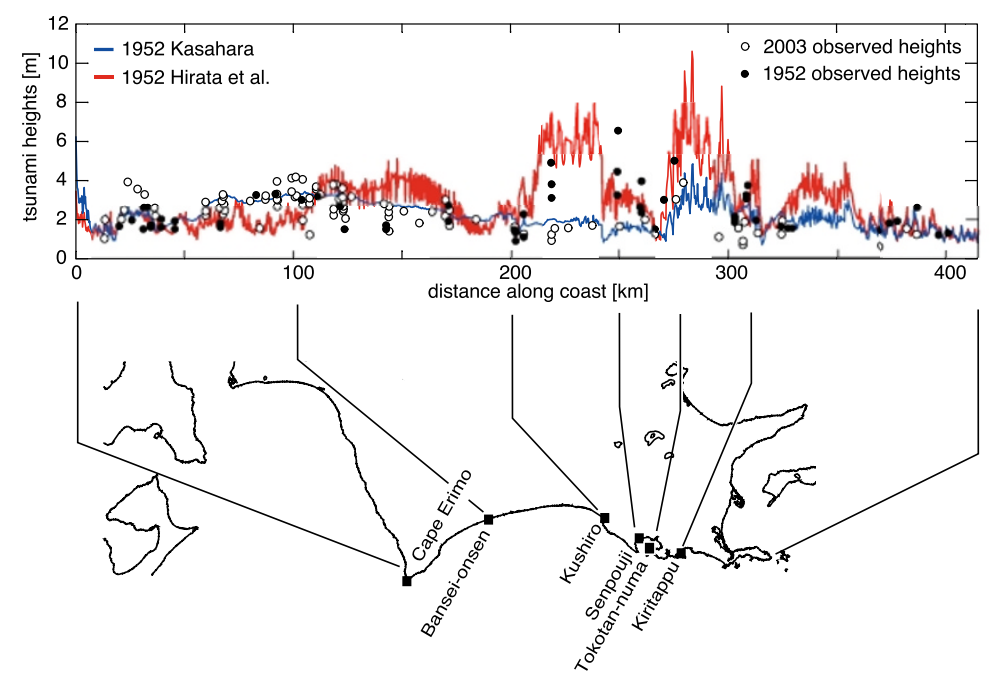

Fig. 4. Maximum coastal tsunami heights along the Pacific coast of eastern Hokkaido from the 1952 and 2003 Tokachi-oki earthquakes (Central Meteorological Agency, 1953; Tanioka et al., 2004b). Solid and open circles are the observed maximum tsunami heights in 1952 and 2003 , respectively. Blue and red lines are computed tsunami heights from Kasahara's (1975) and Hirata et al.'s (2003) fault models, respectively (modified from Hirata et al., 2003).

(\#12), because of long-period components, possibly due to an eigen-oscillation such as a seiche within the port or bay. The long-period component may mask the onset times at Muroran and Hakodate. Otherwise, Region B might be an "apparent" or Huygens' source from a possible diffraction at Cape Erimo. To clarify whether the region B indicates a minor uplift or diffraction source at Cape Erimo, a detailed hydrodynamic modeling would be needed (c.f., Tanioka et al., 2004b).

\section{Discussion and Conclusion}

In the previous section, we have shown by comparing tsunami source areas that the rupture extent of the 2003 Tokachi-oki earthquake is probably restricted within the western half of the 1952 rupture extent. In the eastern-half of the 1952 rupture, a large amount (nearly $8 \mathrm{~m}$ at maximum) of slip was estimated (Hirata et al., 2003). According to the tsunami site survey in 1952, maximum tsunami heights were concentrated locally between Kushiro (\#5) and Kiritappu (\#3). The observed maximum tsunami heights along this section were greater than $4 \mathrm{~m}$ and about $7 \mathrm{~m}$ at Senposhi (Central Meteorological Observatory, 1953). Tsunami heights at other places were less than $2 \mathrm{~m}$ (Central Meteorological Observatory, 1953).

Hirata et al. (2003) investigated why such a strong tsunami concentration appeared locally between Kushiro and Kiritappu in 1952, by comparing the observed maximum tsunami heights and predicted ones from two different fault models: Kasahara (1975) and Hirata et al. (2003). Briefly, Kasahara's (1975) model is applicable for only the western-half of the 1952 rupture, whereas Hirata et al.'s (2003) model, derived from tsunami waveform inversion, includes both the western-half and the eastern-half rupture that includes a high slip region. Their result is shown in Fig. 4 and suggests that the locally large tsunami concentration is well explained by a large amount of slip in the eastern-half (trenchward) of the 1952 rupture.

The 2003 tsunami seems to show a geographical distri-

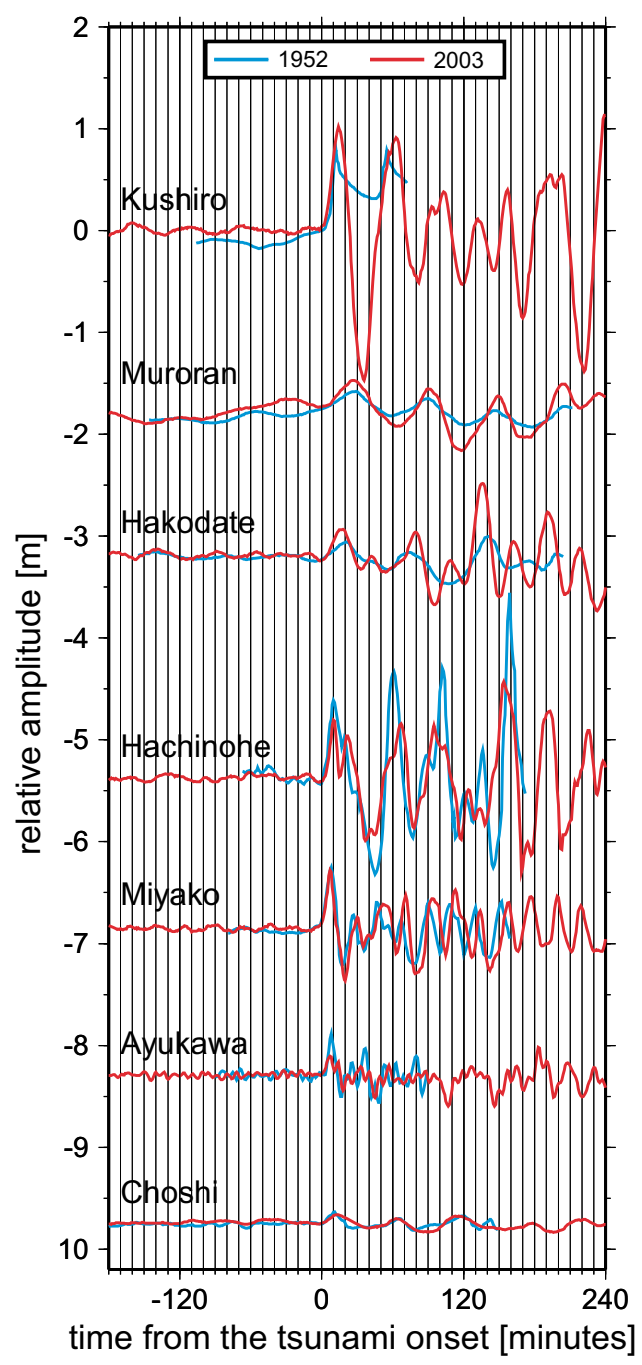

Fig. 5. Comparison of observed tsunami records in 1952 and 2003. Blue and red lines indicate 1952 and 2003 records, respectively. Each record at the same station is aligned so that the onset times of tsunamis are equaled. 
bution of the maximum tsunami heights that differ significantly from the distribution of the 1952 tsunami (Tanioka et al., 2004b). In 2003, the maximum tsunami heights of approximately $4 \mathrm{~m}$ were observed around Cape Erimo and Bansei-onsen (Fig. 4), and decreased gradually to the east (Tanioka et al., 2004b). The observed maximum tsunami heights between Kushiro and Kiritappu in 2003 seem to be less than $2 \mathrm{~m}$ (Tanioka et al., 2004b). Therefore, the difference in the geographical distribution of the observed maximum tsunami heights between the 1952 and 2003 tsunamis support the idea that the 2003 earthquake ruptured only the western-half of the 1952 rupture. It is also interesting that the Kasahara's (1975) model for the 1952 Tokachi-oki earthquake well explain the 2003 tsunami height distribution except around Cape Erimo.

To examine the hypothesis, that is, the 1952 and 2003 tsunami sources, hence rupture areas, were different, the observed tide gauge records are compared. Figure 5 shows a comparison of the observed tide gauge records at the same stations for both the 1952 and 2003 Tokachi-oki earthquakes. Each record at the same station is aligned so that the onset times of the tsunamis are matched. The 1952 records were digitized from a set of negative photographs stocked in a library in JMA but not from other duplicated materials.

Locations of the tide gauge stations, Kushiro, Miyako, and Ayukawa are the same in 1952 and 2003. Stations, Muroran, Hakodate, Hachinohe, and Choshi moved between 1952 and 2003, although they are still located within the same ports. We should first investigate the tide gauge records at Kushiro, Miyako, and Ayukawa; The tide gauge records at Miyako are similar in terms of amplitude, but the tsunami period in 1952 is shorter than that in 2003, supporting that the 1952 tsunami source extended farther eastward (trenchward) than the 2003 source. This suggests that a simple comparison of amplitudes only may be meaningless in determining differences in tsunami source areas. The records at Ayukawa show that the tsunami waveforms are not the same, in particular the waveforms in the first cycle are quite different, with the first few-cycle amplitudes in 1952 being larger than those in 2003. These observations support the hypothesis that the 1952 source was larger than the 2003 source. The record at Kushiro in 1952 shows a strange response due to the flowing of ice blocks into the intake pipe of the tide gauge (Central Meteorological Observatory, 1953). The record can not be used to examine the hypothesis.

The records at Hachinohe also appear to be different although the tide gauge stations in 1952 and 2003 are different. In Muroran and Hakodate, a long-period component is predominant in 1952 and 2003, making interpretation difficult. Choshi is located far from the tsunami source areas so that it is difficult to resolve the similarity or difference between 1952 and 2003. In general, a port configuration including breakwaters is sometimes developed, which probably affect tide gauge records. Therefore, it is difficult to discuss the rupture extent relationship between 1952 and 2003 from a simple tsunami waveform comparison as in Fig. 5. A more detailed examination will be needed.

Finally, a few points are worth mentioning. The first point is that, in Hirata et al. (2003), Kushiro is the only tide gauge station that is located to the north of the 1952 tsunami source. The second is that they used a bathymetric grid size of 1 arc-minute. These points might have limited the accuracy of the inversion of the slip distribution in 1952 by Hirata et al. (2003). Further detailed investigations for both the 1952 and 2003 Tokachi-oki earthquakes and tsunamis is required to evaluate more precisely relationship between 1952 and 2003 events.

Acknowledgments. We would like to thank the Japan Meteorological Agency, the Hokkaido Regional Development Bureau of the Ministry of Land, Infrastructure and Transport, and the Hydrographic and Oceanographic Department of the Japan Coast Guard, for giving us the digital tide gauge records. We thank to Fumihiko Imamura and Minoru Kasahara for their critical reviews, which are valuable to improve the manuscript. We also thank Ms. Satako Mezaki for organizing tide gauge records and materials. Figures were partially drawn using GMT software (Wessel, P. and W. H. F. Smith, EOS Trans. AGU, 76, 329, 1995). This work was partially supported by Special Coordination Funds for Promoting Science and Technology, from Ministry of Education, Sports, Culture, Science and Technology and also by the Grant D02 for Deep-Sea Research from the Japan Marine Science and Technology Center.

\section{References}

The Central Meteorological Observatory, Report of the Tokachi-Oki earthquake of March 4, 1952, Quarterly Journal of Seismology, 17, 135 pp., 1953.

Hatori, T., Reexamination of the wave source of the 1952 Tokachi-Oki tsunami, Zisin, 2, 26, 206-208, 1973 (in Japanese with English abstract and figure captions).

Hirata, K., E. L. Geist, K. Satake, Y. Tanioka, and S. Yamaki, Slip distribution of the 1952 Tokachi-Oki earthquake (M8.1) along the Kuril Trench deduced from tsunami waveform inversion, J. Geophys. Res., 108(B4), 2196, doi:10.1029/2002JB001976, 2003.

Kasahara, M., A fault model of the Tokachi-oki earthquake of 1952, Seismol. Soc. Jpn. Programme Abstr., No. 2, 90, 1975 (in Japanese).

Kikuchi, M. and H. Kanamori, Note on Teleseismic Body-Wave Inversion Program, http://www.eri.u-tokyo.ac.jp/ETAL/KIKUCHI/index.html, 2003.

Tanioka, Y., K. Hirata, R. Hino, and T. Kanazawa, Slip distribution of the 2003 Tokachi-oki earthquake estimated from the tsunami waveform inversion, Earth Planets Space, 56, this issue, 373-376, 2004a.

Tanioka, Y., Y. Nishimura, K. Hirakawa, F. Imamura, I. Abe, Y. Abe, K. Shindou, H. Matsutomi, T. Takahashi, K. Imai, K. Harada, Y. Namegawa, Y. Hasegawa, Y. Hayashi, F. Nanayama, T. Kamataki, Y. Kawata, Y. Fukasawa, S. Koshimura, Y. Hada, Y. Azumai, K. Hirata, A. Kamikawa, A. Yoshikawa, T. Shiga, M. Kobayashi, and S. Masaka, Tsunami run-up heights of the 2003 Tokachi-oki earthquake, Earth Planets Space, 56, this issue, 359-365, 2004b.

Yamanaka, Y. and M. Kikuchi, Source processes of the recurrent Tokachioki earthquake on September 26, 2003, inferred from teleseismic body waves, Earth Planets Space, 55, e21-e24, 2003.

K. Hirata (e-mail: hiratak@jamstec.go.jp), Y. Tanioka, K. Satake, S. Yamaki, and E. L. Geist 